\title{
Chapter 7 \\ Place-Based Solutions for Conservation and Restoration of Social-Ecological Production Landscapes and Seascapes in Asia
}

\author{
Raffaela Kozar, Elson Galang, Jyoti Sedhain, Alvie Alip, \\ Suneetha M Subramanian, and Osamu Saito
}

\begin{abstract}
The relevance of traditional land-use systems in Asia is under threat from externally influenced drivers such as the use of modern agricultural technologies, urbanization, rapid industrialization, overexploitation, and underutilization. The impacts of these changes in land use are contributing to a loss of biodiversity and ecosystem services (BES) in social-ecological production landscapes and seascapes (SEPLS). Societal actors operating from multiple scales create and implement place-based solutions in SEPLS in response to landscape-specific challenges and opportunities for achieving biodiversity conservation and sustainable development. This study aims to identify and demonstrate the abundance of place-based solutions for solving challenges to sustainable use and management of natural resources in SEPLS, and to better inform the existing suite of conservation and restoration solutions. We review a set of 88 case studies from The International Partnership for the Satoyama Initiative (IPSI) in the South, East and Southeast Asian regions using a societal-based solution scanning approach to systematically identify these solutions for conservation and restoration at local scales and to categorize them by solution type. Societal actors demonstrate preferences for solution types to reversing the loss
\end{abstract}

R. Kozar · E. Galang · J. Sedhain · A. Alip

United Nations University Institute for the Advanced Study of Sustainability (UNU-IAS), Tokyo, Japan

S. M. Subramanian

United Nations University International Institute for Global Health (UNU-IIGH),

Cheras, Kuala Lumpur, Malaysia

O. Saito $(\triangle)$

United Nations University Institute for the Advanced Study of Sustainability (UNU-IAS), Shibuya, Tokyo, Japan

Institute for Global Environmental Strategies (IGES), Hayama, Kanagawa, Japan

Institute for Future Initiatives (IFI), The University of Tokyo, Bunkyo, Tokyo, Japan e-mail: saito@unu.edu 
of BES in SEPLS while embracing a mix of all solution types across ecosystems. Institutional and governance solutions are the most common type across Asia. Technological solutions are preferred in East Asia, while knowledge and cognitive solutions are preferred in Southeast Asia. Economic and incentive-based solutions are found most often in South Asia as livelihood investments for local residents, and to balance trade-offs among food production and biodiversity conservation. Sharing the knowledge of various place-based solution types in different social-ecological contexts helps improve more purposeful and deliberate design of SEPLS for multiple benefits.

Keywords Place-based · Solution scanning · Biodiversity conservation · SEPLS · Sustainable development

\subsection{Introduction}

\subsubsection{An Accelerating Loss of Biodiversity and Ecosystem Services in Asia}

Communities across Asia are facing unprecedented threats to traditional natural resource-based livelihoods in managed agricultural landscapes (van Oudenhoven et al. 2010). The loss of biodiversity and ecosystem services (BES) from land-use change is affecting the systems communities have relied on for the sustainable use and management of resources that provide for their livelihoods. This changing relevance of traditional land-use systems in Asia is driven by a number of externally influenced drivers such as the use of modern agricultural technologies, urbanization, rapid industrialization, overexploitation and underutilization. We introduce some of the ways each of these drivers have upset the balance of resource use in turn.

First, the use of modern agricultural technologies has changed the balance of species in some ecosystems (Kumar and Takeuchi 2009; Plieninger et al. 2014; Akça et al. 2015; Katayama et al. 2015; Aadrean 2017). In Taiwan's Shungxi River Valley for instance, farmers' use of chemical fertilizers and pesticides has put great pressure on local aquatic species and other freshwater-based ecosystem services (Yun-Ju et al. 2015). Increasing urban sprawl and changing consumer demands are driving shifts in ecosystem composition, the loss of agrobiodiversity, and the services provided to humans across communities in the region (Kumar and Takeuchi 2009; Knight 2010; Kohsaka et al. 2013; Plieninger et al. 2014; Sakurai et al. 2016; Yu et al. 2016). In Pakistan's Jhelum River Basin, urbanization has been credited with the reduction of wildlife species, shifts of indigenous plant species to nonnative species, and increased contamination of the river (Khan et al. 2017).

Industrialization in South Korea was key to the country's economic growth in the 1960s, but came in part at the expense of the country's traditional rural agricultural 
production landscapes known as "maeuls" (UNU-IAS 2012a). Rapid industrialization is now a factor in the loss of rural production landscapes and the diversity of crops grown within them in multiple countries across Asia (Knight 2010; Shimada 2015; Tomita et al. 2015). Overexploitation of resources from increasing population pressures and multiple demands by actors at different levels, together with poverty and the exacerbating effects of climate change, is a continuing threat to BES in traditional land-use systems (Shimada 2015; Takeuchi et al. 2016). In Cambodia's Chumkiri District, anarchical forest exploitation by both insiders and outsiders has turned the area's semi-jungle forest into a degraded forest, significantly impacting the local people who have long been dependent on various forest-based ecosystem services (Marady et al. 2011).

Finally, underutilization is a relatively unique phenomenon to countries where populations are decreasing or aging and driving the loss of BES through the transformation of abandoned lands to new ecosystems (Putra and Nakamura 2009; Kieninger et al. 2011; Morimoto 2011; Tsuchiya et al. 2013; Plieninger et al. 2014; Queroiz et al. 2014; Katayama et al. 2015; Shimada 2015; Li and Li 2016; Osawa et al. 2016; Takeuchi et al. 2016). For instance, in Japan's Toyooka City, underutilization in the form of abandonment of farmlands served as a major factor in the disappearance of oriental white storks, an important fauna in maintaining the area's wetland ecosystem (Toyooka City 2012).

A recent regional assessment of the status of BES in Asia and the Pacific found that the interaction of these factors and others are accelerating the rate of loss of BES across Asia in ways that are threatening livelihoods and food security, but found that management choices can alter this trajectory (IPBES 2018).

\subsubsection{Community-Based Sustainable Use and Management of Resources}

Communities have practiced varying sustainable resource management approaches in places where multiple ecosystem services for human well-being are derived from patchwork land uses and ecosystems in mosaics with human settlements, known as social-ecological production landscapes or seascapes (SEPLS) (Bélair et al. 2010; Hashimoto et al. 2015). One such approach to managing SEPLS for multiple benefits is embodied in the Japanese concept of "Satoyama," or the balance of society and nature in harmony. Many experiences with the Satoyama tradition of sustainable use and the conservation of SEPLS have been documented (See for instance the volumes of: Subramanian et al. 2015, 2016, 2017, 2018; Okayasu and Matsumoto 2013).

However, the traditional Satoyama approach, which customarily provided multiple ecosystem services and benefits to humans, no longer suffices in practice to deliver the same level, mix or synergies among ecosystem services due to the externally influenced drivers of an accelerating loss of BES that are changing the patterns 
and feedbacks among land use and users at different scales (Takeuchi et al. 2016). In the examples in the preceding section, not only did a loss of BES impact people's livelihoods and well-being, but re-shaped the overall dynamics of diverse and complex social-ecological systems in communities across Asia. Impacts of a loss of BES on water availability and quality, crop productivity, health, nutrition, and food security are causing SEPLS to no longer serve as reliable sources of income and support for the well-being of local residents.

\subsubsection{The New Challenges to Sustainable Use and Management of SEPLS}

The drivers of a loss of BES and their interactions are complex and span multiple scales. They also introduce new demands on the ecosystems in the landscape, while the stakeholders making such demands are increasingly located at multiple socialecological scales. Therefore, local residents together with other societal actors spanning social-ecological scales and seeking to address the same challenge need to work together on the solutions. In the rest of this chapter, we use the term "placebased" solutions to refer to these solutions that are developed for use in a particular SEPLS by societal actors at different social-ecological scales, and that have a wide range of values shaping their preferences for selection of solutions.

Addressing this challenge of an accelerating loss of BES and revitalizing SEPLS in ways that will balance society and nature in harmony requires sustainable use and management approaches that function across multiple scales and that take into account the feedbacks in social-ecological systems (Takeuchi et al. 2016). Therefore, increasingly, approaches to sustainable use and management of SEPLS need to address the multiple externally influenced drivers that are challenging traditional land-use patterns, and also account for the wider range of values from different users from multiple scales, while still meeting the livelihood and well-being of local populations (Gu and Subramanian 2014; Havas et al. 2016; Duraiappah et al. 2014; IPBES 2015; Bohnet and Beilin 2015).

The 2018 IPBES regional assessment for BES in Asia finds that the types of management approaches that can best help address the links among drivers that are accelerating a loss of BES are those that are based on community approaches to sustainable use and management and that link multiple stakeholders and levels through collaborative decision-making processes (IPBES 2018). These types of approaches put communities at the center of defining the priority values of land use and decision-making in the landscape while linking the management functions and jurisdictions over resource governance across scales. These approaches include various forms of a landscape-scale approach to integrated management of the benefits from BES in SEPLS. Not only should these management approaches address ecosystem services today, but also the needed ecosystem services in the future for 
resilient ecosystem function and services across scales (IPBES 2015; Oliver et al. 2015).

New sustainable use and management approaches require a ready suite of implementable solutions for the revitalization and conservation and restoration of BES in SEPLS that can account for these changing dynamics and future needs, while working across multiple actors and scales. In addition, the synergies and trade-offs among conservation and restoration solutions across the mosaic ecosystem character and multiple scales of SEPLS have to outreach the expected impacts of climate change, which are likely to impede progress in development goals in South and Southeast Asia and exacerbate biodiversity loss in the hotspots of Asia if management aims that can meet these criteria are not met (Springmann et al. 2016).

Devising new sustainable use and management approaches that communities can embrace and implement requires understanding how collaboration can deliver multiple solutions that can balance multiple functions in SEPLS and that benefit multiple stakeholders (Cockburn et al. 2018; Freeman et al. 2015). The next section looks at how readily deployable conservation and restoration solutions are to meet the challenges to sustainable use and management of SEPLS.

\subsubsection{Conservation and Restoration Solutions for SEPLS}

Conservation and restoration solutions in SEPLS redress the loss of BES from landuse change. Extensive work has been done to catalog these conservation solutions based on expert knowledge (Sutherland et al. 2017; see for instance Dicks et al. 2016). Yet the wealth of solutions held by societal actors have not been given the same weight as expert opinion in the scientific evidence base for effective solutions. To meet the most pressing sustainability challenges in biodiversity and climate, science and evidence-based solutions are not enough.

Societal actors are those that form in response to a given challenge at a given point in time or over a period of time to provide solutions. Communities across Asia are working together with other societal actors from across scales to implement place-based solutions in response to the challenges and opportunities for achieving biodiversity conservation and sustainable development in SEPLS. A better understanding of these place-based solutions and how they can be selected and utilized for sustainable use and management can help expand the current state of knowledge of conservation and restoration solutions with the best available knowledge reflecting multiple values (Jacobs et al. 2016). Integrating multiple knowledges enriches solutions and leads to the potential for place-based solutions not previously under consideration or those that reflect the dynamics of changing landscapes, while increasing acceptability among societal actors with different values.

This study aims to identify and demonstrate the abundance of place-based solutions for solving challenges to sustainable use and management of natural resources in SEPLS, and to better inform the existing suite of conservation and restoration solutions in the scientific literature with the experiences of societal actors. 
The rest of this chapter is organized as follows. Section 7.2 describes the methodology for a societal-based approach to systematically identifying solutions. The third section describes the experiences of local residents in navigating solutions with other societal actors at different scales and across ecosystems. Section 7.4 explores the socio-environmental contexts of different solutions and discusses their implications for informing sustainable use and management approaches. The final section draws some conclusions and suggests areas that need further attention in advancing conservation and restoration solutions that deliver sustainable use and management of SEPLS in the context of pressing sustainability challenges in biodiversity and climate.

\subsection{Methodology}

\subsubsection{A Societal-Based Approach to Solution Scanning}

Solution scanning is a systematic process of making an inventory of all possible responses to a problem prior to weighing the feasibility and merit of each solution for use in a particular setting (Sutherland et al. 2014). It's been used in environmental and sustainability research literatures to identify solutions for maintaining ecosystem services (Sutherland et al. 2014), agroforestry-based solutions for climate mitigation and adaptation (Hernández-Morcillo et al. 2018) and to scan for existing food network models as a solution type in cultural landscapes in Europe and Asia (Plieninger et al. 2018). The three-part cycle starts with problem identification (horizon scan), then secondly the solution scan, and third the filtering process, which is how solutions can be weighed and selected for their effectiveness in a particular context (Sutherland et al. 2014).

In a recent review of multi-level networks and sustainability solutions, we proposed a societal-based solution scanning approach (Kozar et al. 2019). Transdisciplinary methods that engage multiple types of knowledge, when used with a sustainability science framework focused on societally relevant problems, can help address the questions related to which solutions for a loss of BES can be most effective in managing SEPLS (Pascual et al. 2017). These solutions should be selected for paths that preserve the multiple benefits and ecosystem services borne by traditional management systems, while considering current and future needs through multiple stakeholder values at multiple levels and across the mosaic ecosystem character of SEPLS. 


\subsubsection{Methods}

This chapter presents place-based solutions for conservation and restoration of SEPLS in the Asian region. These are presented: (1) in different sub-regions of Asia at the local scale, (2) by ecosystem, and (3) by how they are connected to other scales through multi-level governance by coalitions of societal actors. We drew upon the experiences of the International Partnership for the Satoyama Initiative (IPSI) in identifying and implementing solutions. ${ }^{1}$ IPSI seeks to conserve and revitalize SEPLS through rejuvenation of the Satoyama approach in social-ecological systems that face current environmental challenges from land-use changes. IPSI does this while sustainably supporting the livelihoods and well-being of local communities through revitalized, adaptive and innovative production and management systems that are evolved from cultural practices and indigenous and community knowledge (Gu and Subramanian 2014; Takeuchi et al. 2016; Berglund et al. 2014).

IPSI is a coalition of societal actors that have agreed to share knowledge and collaborate to improve the management of SEPLS in response to evolving threats, including the loss of BES caused by the interactions of a multitude of externally influenced drivers. In Step 1, the horizon scan, the problem we chose to focus on is the one identified by the societal actors of the IPSI network, which is a loss of biodiversity and ecosystem services. The network has aimed to share place-based solutions to this problem over the past decade.

For step 2, the solution scan, we selected case studies from all publicly available IPSI member cases up to March of 2018. Cases are from 2009 to 2017 and from four primary sources: (1) an online case study database hosted by IPSI (UNU-IAS 2018); (2) a publication by the Satoyama Initiative on Asian production landscapes (UNU-IAS 2012b); (3) publications from the Communities in Action for Landscape Resilience and Sustainability-The COMDEKS program, produced through a collaborative activity of IPSI (UNDP 2014a, 2016); and (4) the flagship series of the Satoyama Initiative, its annual thematic review (Subramanian et al. 2015, 2016, 2017).

We used a set of categorical variables collected in a Microsoft Excel based data instrument. Data collection instruments were created and refined through consultations and pre-testing. A data definition and collection guide was developed to inform the data collection process, and included variables and their range of values, definition, and collection instructions. Quality assurance was controlled through three rounds of pre-testing the data collection sheet by the research team made up of the authors, whereby after each round the range of values and definitions were revised by the shared understanding among team members. Another quality assurance mea-

\footnotetext{
${ }^{1}$ The International Satoyama Initiative (ISI) was jointly initiated by the Ministry of the Environment of Japan (MOEJ) and the United Nations University Institute for the Advanced Study of Sustainability (UNU-IAS). On 19 October 2010, during the tenth meeting of the Conference of the Parties to the Convention on Biological Diversity (CBD COP 10), the International Partnership for the Satoyama Initiative (IPSI) was established to promote the activities identified by ISI and to share relevant information and experiences.
} 
sure included the use of a pre-defined set of values for many of the variables in the data collection sheet to reduce error in data entry, and the aforementioned guide to definitions and response types for the remaining open entry cells. Finally, after data entry, responses were standardized with consistent terms, and various consistency checks performed.

Types of data collected included case study information (publication year, location, scale, institutional author); socioeconomic and biophysical information (sectors, stakeholders, institutions, livelihoods, threats, ecosystems, and ecosystem products); program information (goals, institutional and legal environment, outcomes, knowledge mechanisms); and solutions (solution, solution type). We defined a solution as any activity, intervention, innovation, practice, strategy, or policy that has been proposed or applied in the case study area to address the given problem.

Data for 91 cases was recorded. A minimum criteria was set for each case study to include at least one solution and at least one value for all data categories in the socioeconomic and biophysical section. One case was excluded that did not meet the minimum criteria. A data cleaning protocol was applied to the remaining 90 cases. During the data cleaning, data from case studies in the same location and with the same institutional author were merged in 2 cases, resulting in a total of 88 cases. The final number of case studies and their geographical locations are shown in Table 7.1. A total of 23 cases are located in South Asia, 29 cases in Southeast Asia, and 36 cases in East Asia, representing 18 countries in these regions. Fifty-two local-scale cases were identified by reviewing these 88 case studies, and those countries with local-scale cases are indicated in bold script in Table 7.1.

For step 3, the filtering process for selection of solutions to apply in a particular context, we did not discuss or evaluate solutions based on their effectiveness for a particular place. Rather, we applied a framework to filter the solutions by solution type (adapted from the Millennium Ecosystem Assessment 2005) in order to understand which type of solutions societal actors might prioritize in different socialecological contexts.

Table 7.1 Location and number of study cases from the International Partnership for the Satoyama Initiative (IPSI)

\begin{tabular}{l|l|l}
\hline Southeast Asia & South Asia & East Asia \\
\hline Cambodia (8) & Bangladesh (1) & China (15) \\
\hline Indonesia (6) & Bhutan (2) & Japan (18) \\
\hline $\begin{array}{l}\text { Lao People's Democratic Republic } \\
\text { (1) }\end{array}$ & India (9) & Mongolia (2) \\
\hline Myanmar (1) & Iran (1) & South Korea (1) \\
\hline Philippines (5) & Nepal (7) & Total 36 \\
\hline Vietnam (4) & Pakistan (2) & \\
\hline Thailand (4) & Sri Lanka (1) & \\
\hline Total 29 & Total 23 & \\
\hline
\end{tabular}

Bold font indicates countries with local-scale case studies. Numbers in parenthesis indicate the number of case studies included in the total 88 cases of the review 
A workshop was held with the research team. Using a consensus process, the solutions were categorized and a further typology of 25 sub-categories was developed. Solutions for the 88 case studies were categorized according to the following 5 categories: institutional and governance solutions; economic and incentive-based solutions; social, cultural, and behavioral solutions; knowledge and cognitive solutions; and technological solutions (Table 7.2).

The conventional step 3 filtering process of the solution scan method aims to determine which solution should be applied in a certain place and context based on some agreed expert criteria for effectiveness such as budget, feasibility, and time. In a societal-based solution scanning approach, which solutions to apply in a given SEPLS should be determined in a place-specific and transdisciplinary manner, including knowledge from societal actors on the preferred benefits and trade-offs in the process.

Ecosystems in the case studies were recorded according to the ten classification types of the Millennium Ecosystem Assessment (marine, coastal, inland water, forest, dryland, island, mountain, polar, cultivated, urban) (MA 2005). Up to four ecosystems per case study were recorded to capture the mosaic characteristic of SEPLS. ${ }^{2}$ No cases were located in polar and marine ecosystems in the overall set of 88 cases.

In this chapter, the results discussed present those solutions identified at local scales. These scales are at village, sub-municipality, and local government levels on social and administrative scales, and water bodies (river, lake) or watershed scales at ecological scales. They include both solutions already existing and implemented in the case study areas and those that are proposed as solutions to the given challenge. We examined a sub-set of 52 case studies to answer our question on subregional experiences, the societal actors engaged in navigating solutions and the ecosystems targeted through local-level solutions.

\subsection{Experiences, Actors, and Ecosystems in Navigating Place-Based Solutions}

Solutions at the local scale represent 283 solutions in 52 case studies, or $58 \%$ of the total 485 solutions identified in 88 case studies (Kozar et al. 2019). When comparing the distribution in choice of solutions by solution type between the local scale and higher scales (other administrative or ecological scales such as national level or coastline), institutional and governance solution types are selected more often at higher scales, 34-26\% (Table 7.3). Technological solutions are more often selected at local scales, $21-12 \%$. Solution types are more evenly distributed at local scales, compared to higher scales where there is a $15 \%$ higher rate of selection for institu-

\footnotetext{
${ }^{2}$ Analysis of findings per ecosystem in this chapter is in regard to the "first" or main ecosystem representing the case study area.
} 
Table 7.2 Categories and sub-categories of solutions

\begin{tabular}{|c|c|c|}
\hline Solution type & Description & Sub-categories \\
\hline \multirow[t]{6}{*}{$\begin{array}{l}\text { Institutional and } \\
\text { governance }\end{array}$} & \multirow{6}{*}{$\begin{array}{l}\text { Solutions that enhance benefits while conserving } \\
\text { resources by addressing weak or insufficient } \\
\text { institutional and management systems and with } \\
\text { coordinated responses at multiple scales that } \\
\text { consider regulation of ecosystem services in the } \\
\text { long term }\end{array}$} & $\begin{array}{l}\text { - Organizational } \\
\text { development and } \\
\text { institutional } \\
\text { strengthening }\end{array}$ \\
\hline & & $\begin{array}{l}\cdot \quad \text { Integrated } \\
\text { management approaches }\end{array}$ \\
\hline & & $\begin{array}{l}\text { - Regulations, policies, } \\
\text { or frameworks }\end{array}$ \\
\hline & & - Inclusion \\
\hline & & - Financing \\
\hline & & - Enabling conditions \\
\hline \multirow{7}{*}{$\begin{array}{l}\text { Economic and } \\
\text { incentive-based }\end{array}$} & \multirow{7}{*}{$\begin{array}{l}\text { Solutions that address market failures and } \\
\text { misalignment through market-based approaches } \\
\text { along with improved value-chains and consumer } \\
\text { preferences }\end{array}$} & - Taxes and user fees \\
\hline & & $\begin{array}{l}\text { - Subsidies, payments, } \\
\text { and rewards }\end{array}$ \\
\hline & & $\begin{array}{l}\text { Improved } \\
\text { value-chains }\end{array}$ \\
\hline & & $\begin{array}{l}\text { - Consumer } \\
\text { preferences }\end{array}$ \\
\hline & & - Trade systems \\
\hline & & - Livelihood \\
\hline & & - Market access \\
\hline \multirow[t]{4}{*}{$\begin{array}{l}\text { Social, cultural, } \\
\text { and behavioral }\end{array}$} & \multirow{4}{*}{$\begin{array}{l}\text { Solutions that reduce demand or consumption or } \\
\text { address the lack of political and economic power } \\
\text { of some groups who are particularly dependent } \\
\text { on ecosystem services or harmed by their } \\
\text { degradation through demand-side responses }\end{array}$} & $\begin{array}{l}\text { - Formal and } \\
\text { nonformal education }\end{array}$ \\
\hline & & - Awareness creation \\
\hline & & - Cultural practices \\
\hline & & $\begin{array}{l}\text { - Access to social } \\
\text { services }\end{array}$ \\
\hline \multirow[t]{4}{*}{$\begin{array}{l}\text { Knowledge and } \\
\text { cognitive }\end{array}$} & \multirow{4}{*}{$\begin{array}{l}\text { Solutions that address insufficient knowledge or } \\
\text { the poor use of existing knowledge concerning } \\
\text { ecosystem services, address information gaps } \\
\text { and incorporate other forms of knowledge and } \\
\text { information }\end{array}$} & $\begin{array}{l}\text { - Knowledge } \\
\text { integration }\end{array}$ \\
\hline & & - Knowledge gaps \\
\hline & & $\begin{array}{l}\text { Knowledge } \\
\text { capacities }\end{array}$ \\
\hline & & - Knowledge systems \\
\hline \multirow[t]{4}{*}{ Technological } & \multirow{4}{*}{$\begin{array}{l}\text { Solutions that reduce the harmful impacts of } \\
\text { various drivers of ecosystem change as well as } \\
\text { underinvestment in the development and } \\
\text { diffusion of technologies, or that could increase } \\
\text { the efficiency of resource use or ecosystems }\end{array}$} & $\begin{array}{l}\text { - Agroecological } \\
\text { practices }\end{array}$ \\
\hline & & $\begin{array}{l}\text { - Ecological } \\
\text { restoration or } \\
\text { conservation practices }\end{array}$ \\
\hline & & $\begin{array}{l}\text { - Energy technologies } \\
\text { or investments }\end{array}$ \\
\hline & & $\begin{array}{l}\text { - Green and resilient } \\
\text { infrastructure }\end{array}$ \\
\hline
\end{tabular}

Adapted from MA (2005) 
7 Place-Based Solutions for Conservation and Restoration of Social-Ecological...

Table 7.3 Solutions by type at local and other scales, and overall, by number and percent

\begin{tabular}{l|c|c|c}
\hline & Local (\%) & $\begin{array}{l}\text { Other administrative or } \\
\text { ecological scale (\%) }\end{array}$ & Overall results (\%) \\
\hline $\begin{array}{l}\text { Economic and } \\
\text { incentive-based }\end{array}$ & $57(20)$ & $36(18)$ & $93(19)$ \\
\hline $\begin{array}{l}\text { Institutional and } \\
\text { governance }\end{array}$ & $74(26)$ & $68(34)$ & $142(29)$ \\
\hline $\begin{array}{l}\text { Knowledge and cognitive } \\
\begin{array}{l}\text { Social, cultural, and } \\
\text { behavioral }\end{array}\end{array}$ & $42(15)$ & $34(17)$ & $76(16)$ \\
\hline Technological & $50(18)$ & $39(19)$ & $89(18)$ \\
\hline Total & $60(21)$ & $25(12)$ & $85(18)$ \\
\hline
\end{tabular}

tional and governance solutions (34\%) relative to the rate of selection of the next most often selected solution type, social, cultural, and behavioral (19\%). The distribution among the 5 solution types at local scales compared with the overall distribution among 485 solutions does not show a demonstrable difference.

We now turn to look at how these solution types break down in experiences per sub-region, among societal actors, and in different ecosystems.

\subsubsection{Sub-regional Experiences and Variation of Place-Based Solutions}

Sub-regions demonstrate solution type preferences in different social-ecological contexts (Fig. 7.1). We performed a chi-square test to test the association between solution type and geographical location. The results are found in Table 7.4. We found a significant association for sub-region and the four solution types with the highest difference in proportion of solution type among sub-regions (institutional, technological, knowledge, and economic) for the local-scale solution set $(n=233$; $p=0.035)$ and for the whole solution set $(n=396 ; p=0.030)$. No significant association was found between geographical location and all five solution types including the social, cultural, and behavioral solution type $(n=485 ; p=0.055)$.

In the discussions below, a number of solution sub-types (for instance, ecological conservation under the technological solution type) are included in the examples and discussion. In some cases, there are a small number of each of these individual solution sub-types in our sample, while there are many examples of such activities in the sub-regions.

Institutional and governance type solutions are the most common solution type across Asia. Institutional and governance type solutions show a similar pattern at the sub-regional level and are a significant proportion of solution types regardless of geography, making up at minimum one quarter of solutions in each sub-region (Fig. 7.1). Inclusion is the highest selected solution of institutional and governance 


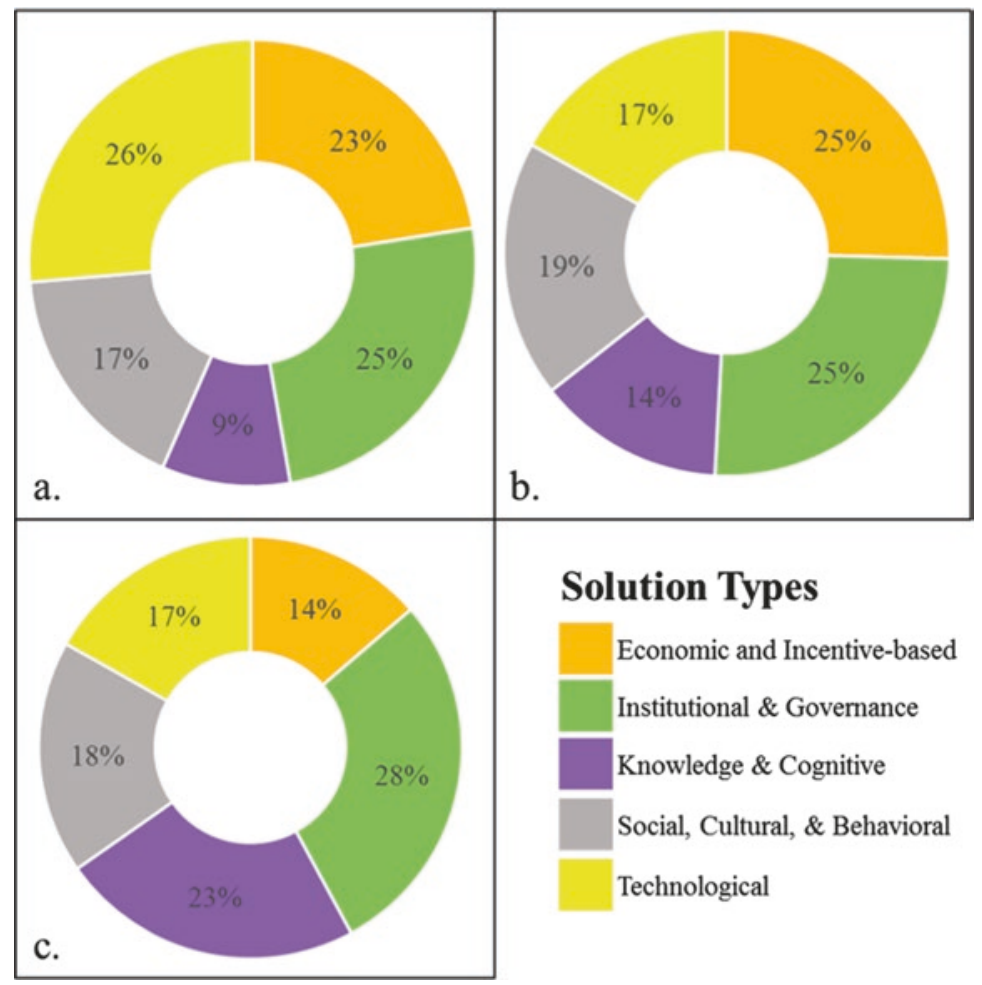

Fig. 7.1 Local-scale solutions by solution type and sub-region, in percent. (a) East Asia, (b) South Asia, (c) Southeast Asia

solution sub-types at the local level in all three sub-regions (Fig. 7.2). These solutions target an increase in the number of categories of actors that hold benefit rights or that are included in decision-making processes.

Social, cultural, and behavioral type solutions are represented in even proportions across the region, with an average of $18 \%$ in each sub-region. South Asia has more than double the proportion of solutions for access to social services compared to Southeast Asia. Although the result is not significant with regard to an association between sub-region and social and behavioral solution types, we can expect a higher investment in basic social services such as access to water and development activities in SEPLS in South Asia where a number of the case study countries (India, Bhutan, Nepal) have high poverty rates.

Technological solutions are preferred in East Asia at a rate of 1.5 times over other sub-regions. In East Asia, technological solutions make up 26\% of the proportion of solutions selected (Fig. 7.1a), while the figures are 17\% in South and Southeast Asia, respectively (Fig. 7.1b, c). The preference for technological responses in East Asia is driven by a higher emphasis on incorporating agroecological practices such as sustainable agriculture in SEPLS management, as well as renewable energy investments that are double those of Southeast Asia and are nil in South Asia. 
Table 7.4 Summary of chi-square results for solution type and geographic location (East, South, and Southeast sub-regions)

\begin{tabular}{|c|c|c|c|c|}
\hline \multirow[b]{2}{*}{ Cases } & \multirow[b]{2}{*}{ Solution types tested } & \multirow[b]{2}{*}{$\begin{array}{l}\text { Number of } \\
\text { solutions }\end{array}$} & \multicolumn{2}{|c|}{$\begin{array}{l}\text { Association with sub-regions } \\
\text { (Pearson Chi-Square) }\end{array}$} \\
\hline & & & Test statistic & $\begin{array}{l}\text { Asymp. Sig } \\
\text { (2-sided) }\end{array}$ \\
\hline $\begin{array}{l}\text { Local scales } \\
\text { only } \\
\text { Four } \\
\text { solution } \\
\text { types }\end{array}$ & $\begin{array}{l}\text { Institutional, economic, } \\
\text { knowledge, technological }\end{array}$ & $n=233$ & $13.543^{\mathrm{a}}$ & $0.035^{b}$ \\
\hline $\begin{array}{l}\text { All scales } \\
\text { Four } \\
\text { solution } \\
\text { types }\end{array}$ & $\begin{array}{l}\text { Institutional, economic, } \\
\text { knowledge, technological }\end{array}$ & $n=396$ & $13.993^{c}$ & $\mathbf{0 . 0 3 0}^{\mathrm{b}}$ \\
\hline $\begin{array}{l}\text { All scales } \\
\text { Five } \\
\text { solution } \\
\text { types }\end{array}$ & $\begin{array}{l}\text { Institutional, economic, } \\
\text { knowledge, technological, } \\
\text { social }\end{array}$ & $n=485$ & $15.239^{\mathrm{d}}$ & 0.055 \\
\hline
\end{tabular}

${ }^{\mathrm{a}} N$ of valid cases $=233.0$ cells $(0.0 \%)$ have expected count less than 5 . The minimum expected count is 8.65

\section{${ }^{\mathrm{b}}$ Significant result}

${ }^{\mathrm{c}} N$ of valid cases $=396.0$ cells $(0.0 \%)$ have expected count less than 5 . The minimum expected count is 21.30

${ }^{\mathrm{d}} N$ of valid cases $=485.0$ cells $(0.0 \%)$ have expected count less than 5 . The minimum expected count is 22.09

Knowledge and cognitive type solutions are preferred in Southeast Asia at a rate of 2.5 times that of East Asia. In Southeast Asia, knowledge and cognitive type solutions make up $23 \%$ of the proportion of solutions (Fig. 7.1c), compared with just 14\% in South Asia and 9\% in East Asia (Fig. 7.1a, b). In Southeast Asia, local communities in SEPLS invest more often in all sub-types of knowledge and cognitive type solutions at nearly double the rate of the other sub-regions. These include capacity building (knowledge capacities), monitoring and evaluation systems (knowledge systems), and bridging knowledge forms from communities and science (knowledge integration). For instance in the Philippines, local ecological knowledge of ethnic groups is included in practical learning experiences in farmer field schools, and helps bridge local knowledge systems with new technical developments (Dang 2015). The exception is for assessments and research (knowledge gaps), which are selected in a slightly higher proportion in East Asia.

In South Asia, economic and incentive-based solutions are preferred more often than in Southeast Asia, 25\% compared with 14\%, respectively (Fig. 7.1b, c). While the proportion of economic-based solutions are similar in East Asia (23\%) to South Asia, the distribution of solution sub-types is different among the two sub-regions. In South Asia, there is a clear preference for livelihood-based solutions that include both investments in existing livelihoods and the creation of new livelihood opportu- 


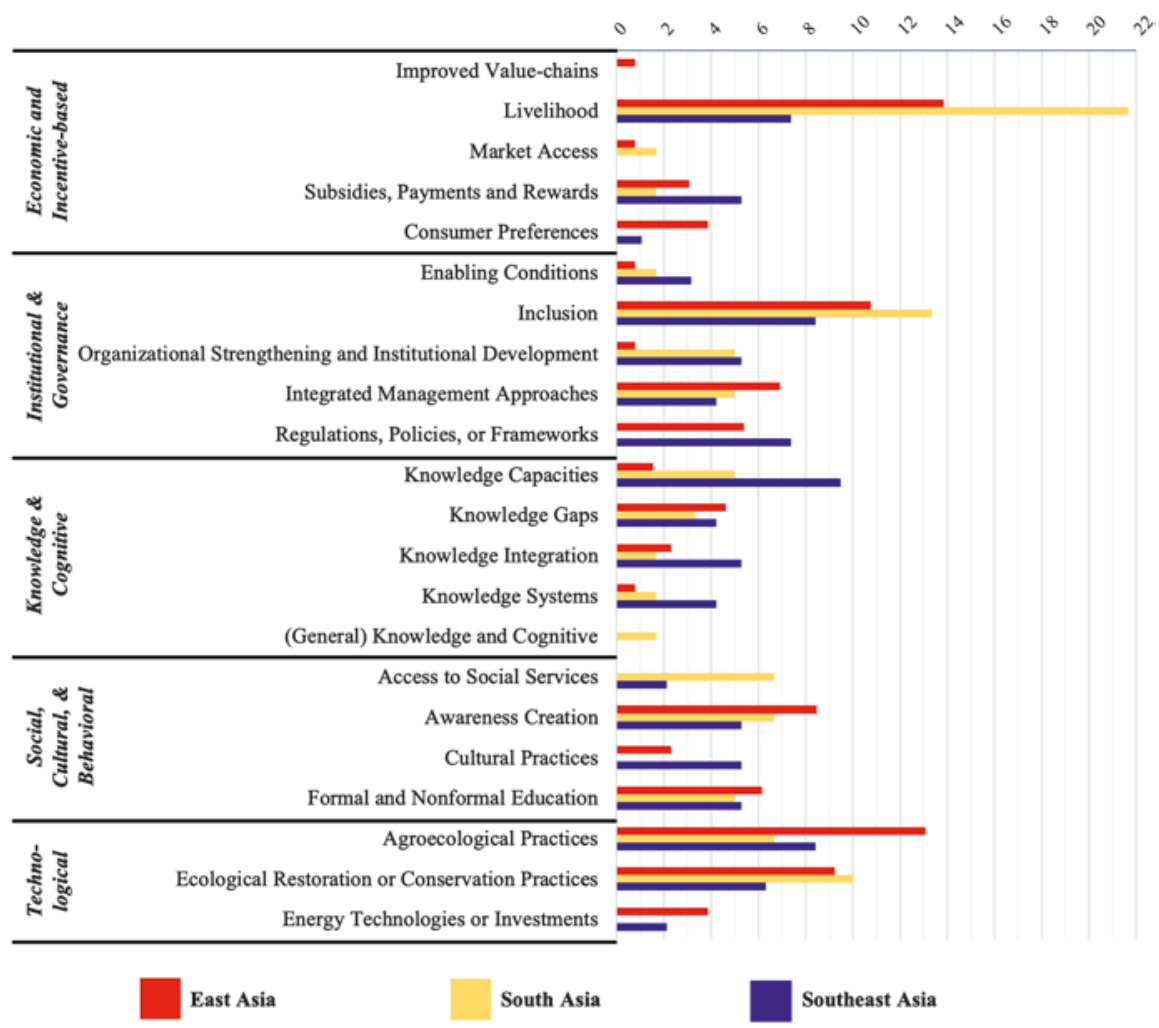

Fig. 7.2 Local-scale solutions per subcategory of solution type and per sub-region, in percent per solution type

nities. Livelihood solutions also represent the highest overall proportion of any solution sub-type.

There are a few instances of unique solutions in sub-regions. For instance, investments in improved value-chains are found only in East Asia at the local scale. One such case included the addition of a local bamboo processing industry in China (Yiping 2011). In several cases, one sub-region does not select solution types found in the other two sub-regions. Consumer preference schemes such as eco-labelling of environmentally-friendly rice in Taiwan (economic); cultural practices such as "muyong" in the Philippines that guide private forest land owners to act flexibly with regard to sustainable community resource management (social and cultural); regulations, policies, and frameworks such as community action plans at the local scale (institutional and governance); and renewable energy investments (technological) are not found in South Asia at the local scale (Fan et al. 2016; UNU-IAS 2012c). Market access interventions such as the creation of new local businesses that create markets for locally grown produce in the revitalization of small towns in 
Japan are not found in Southeast Asia (Matsui et al. 2010). Access to basic social services such as clean drinking water (social and cultural) is not found in East Asia.

Taxes and user fees (economic) and financing (institutional and governance) do not appear as local-scale solutions but are found in the overall set of solutions, although such solutions are possible at the scale of local or village government.

\subsubsection{Sub-regional Multi-stakeholder Coalitions for Conservation and Restoration Solutions in SEPLS}

Across the IPSI network in Asia, there is strong evidence that communities are working with additional societal actors at multiple levels to achieve conservation and restoration solutions. In landscape coalitions, local communities and community-based organizations form the basis of multi-stakeholder coalitions. They represent just under one quarter of all actors and are engaged with a wide range of other stakeholders, in total 18 types of partners at different scales across 4 broad stakeholder groups (public, nongovernmental, research, community) (Fig. 7.3). In each sub-region 16 to all 18 of these partner types are found, and they include all four broad stakeholder groups in each sub-region.

However, the types of stakeholders in partnership with communities in landscape coalitions do demonstrate different sub-regional compositions depending on sociopolitical contexts. In Southeast Asia for instance, coalitions are more heavily made up of public sector engagement from local or national sector ministries and individual leaders at multiple scales. Such leaders are commonly an extension agent such as a District Forest Officer. Sectoral ministries are less engaged in solutions in SEPLS in South Asia in our sample.

The compositions of societal actors in coalitions in other sub-regions may reflect states of economic development. Local and national research institutions are engaged at double the rate in East Asia compared with the other two sub-regions, while foreign government engagement is not found at all, likely reflecting the more developed economies of Japan and China and more developed national research institutes and facilities. And while it's more common to find mention of individual leaders that drove conservation and restoration solutions in SEPLS outside of East Asia, local governments are engaged at double the rate in East Asia than Southeast Asia.

In South Asia, engagement of intergovernmental organizations is more prevalent, often to provide technical support or capacity building for development project implementation in SEPLS. Similarly, in South Asia engagement of the nongovernmental sector in coalitions is strong. Local and international NGOs are found at about double the rate in South and East Asia than in Southeast Asia. Civil society institutions are also a strong development partner in South Asia. In addition, community-based institutions representing indigenous and ethnic groups are found 


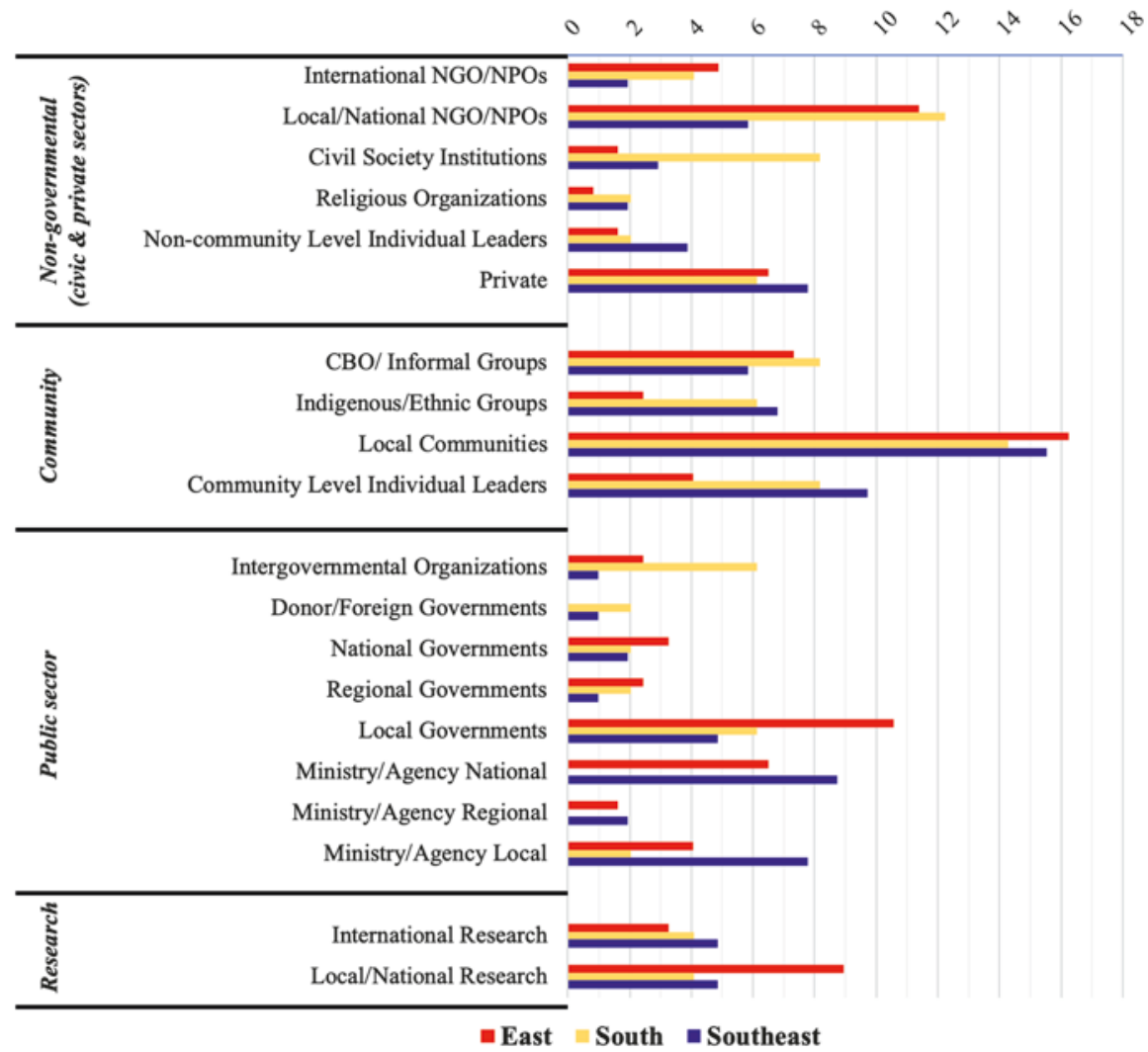

Fig. 7.3 Types of stakeholders engaged in conservation and restoration solutions in SEPLS at the local scale, by sub-region, in percent of total

at triple the rate in South and Southeast Asia than in East Asia, and participate in development and natural resource management activities in SEPLS.

Private sector and international research institutions appear to invest in cooperating or engaging in multi-stakeholder management of SEPLS at about the same rate across the three sub-regions.

\subsubsection{Mosaic Landscapes of Multiple Ecosystems}

The relationships of solutions across spatial scales in the eight ecosystems are shown in Fig. 7.4. Solutions tend to be planned at social and administrative scales rather than ecological scales. When planning is done at ecological scales it tends not to be at the local scales, with the exception of inland water ecosystems. For instance 


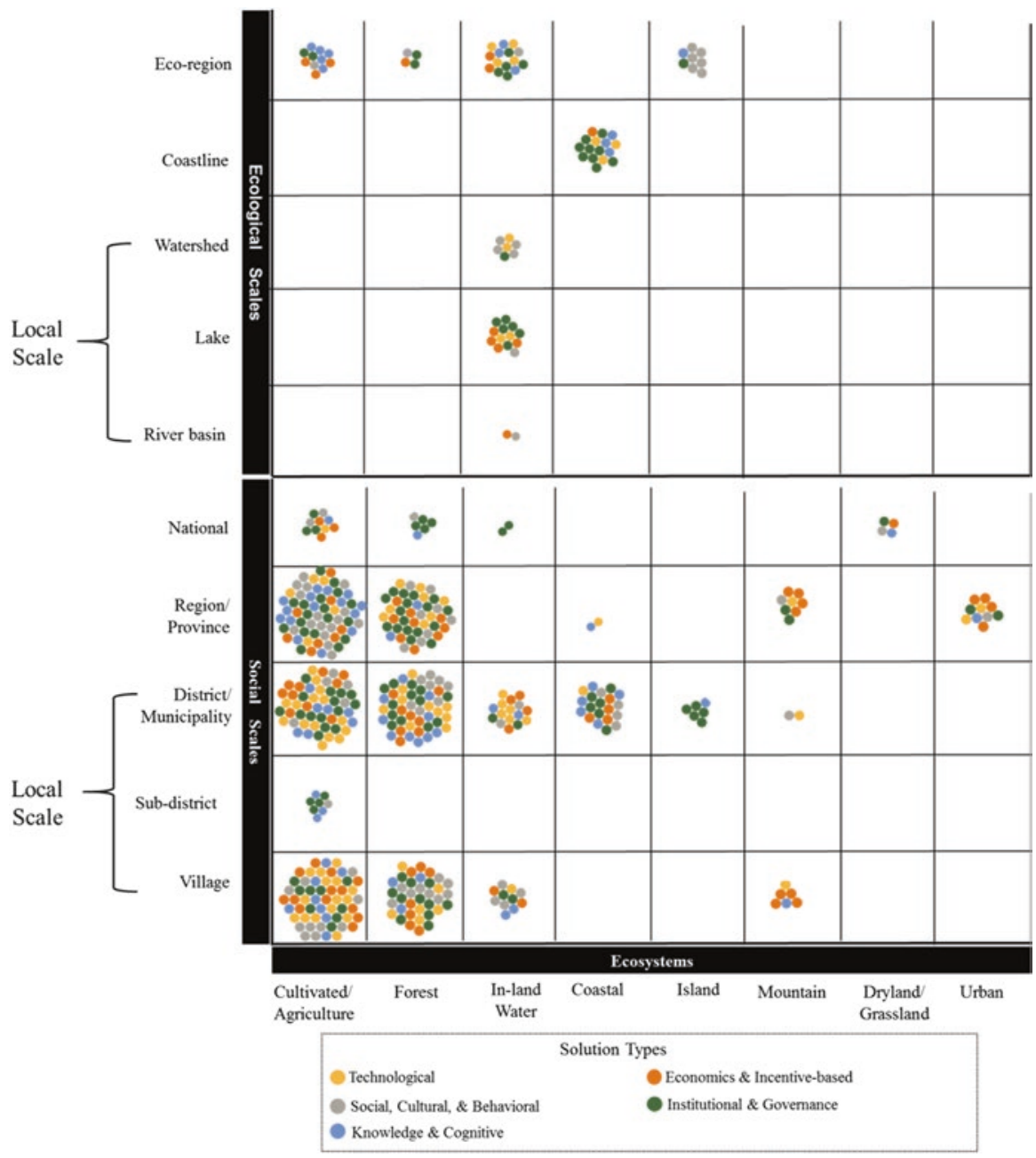

Fig. 7.4 Solutions per solution type, by social and ecological scales and ecosystem. Local social scales include village to district/municipality and ecological scales from river basin to watershed. (Source: Kozar et al. 2019 reprinted with permission from Elsevier)

in cultivated and forest ecosystems, solutions are only planned at local social and administrative scales and not at local ecological scales.

Solutions have the highest concentrations in cultivated and forest ecosystems. Although cultivated and forest ecosystems each make up roughly the same proportion of overall ecosystems found in SEPLS across the 88 cases, at the local scales, solutions are targeted at a $32 \%$ greater rate in cultivated ecosystems than forest ecosystems. In forest ecosystems, institutional and governance solution types are selected at about twice the rate of knowledge solution types. Relative to cultivated ecosystems, there is a preference for social and cultural solution types in forest 
ecosystems, while relative to forest ecosystems, we find a preference for technological solution types in cultivated ecosystems.

Inland water ecosystems are the only one of the eight ecosystems found in IPSI member experiences where solutions are part of sustainable use and management schemes planned at local ecological scales including river basins, freshwater lakes, and watershed or catchment areas. In inland water ecosystems, knowledge solution types are not present in implementing sustainable use and management approaches at local ecological scales, and knowledge solutions make up the lowest proportion of solution types in inland water ecosystems even when including those planned at administrative scales. Knowledge solutions are selected at two to three times less often a rate than other solution types in inland water ecosystems.

Institutional and governance solution types were not found at local scales in mountain ecosystems, while they were found in island and coastal ecosystems at a local government scale at about two times the rate to all other solution types. None of the 52 cases at local scales were found in dryland or urban ecosystems. Solutions in coastal and island ecosystems were planned only at the district or municipality level at local scales.

\subsection{Discussion}

\subsubsection{Selecting Place-Based Solutions for Different Social-Ecological Systems}

Solution types, coalitions of societal actors, and targeted ecosystems and scales do show variances per sub-region and overall patterns in the experiences of IPSI members in Asia (Figs. 7.1, 7.2, 7.3, and 7.4). We discuss some of the factors that may account for these differences in patterns by sub-region.

The preference for technological responses in East Asia, particularly for agroecological solutions (Fig. 7.2), can be ascribed to the recognition of the impacts of modernized agriculture in countries such as Japan, Korea, Taiwan, and China. Japan and China have among some of highest rates of pesticide use worldwide, ${ }^{3}$ and the impacts of these practices on key species important for high-value crops triggered local communities to shift to more eco-friendly farming practices. In Taiwan, farmers developed new production systems based on ecological practices (Chao 2018). In Japan and China, species such as the Oriental White Stork in the Hyogo Tajima region of Japan and the Crested Ibis in China inspired the adoption of agroecological farming practices that would restore and create a habitat for these species to

\footnotetext{
${ }^{3}$ Japan, Taiwan, and China are in the highest bracket of countries worldwide, and Korea follows in the second highest country bracket, per tonnes of active ingredients of pesticides, averaged 1990 2016. Both China and Japan are in the top ten countries. http://www.fao.org/faostat/en/\#data/RP/ visualize (accessed January 29, 2019).
} 
cohabitate in cultivated ecosystems (Ichikawa 2012; Ohsako 2011). There is also a relatively higher engagement of national and local research institutes in East Asia that may support the research needed to develop localized technical solutions.

The higher selection of solutions such as learning processes or training programs (Figs. 7.1 and 7.2) demonstrates the preference for more knowledge-based approaches to achieving agroecological farming and forest harvesting in Southeast Asia, whereas we saw a more technical approach in East Asia to meet the same aim. Knowledge investments in Southeast Asia include: the practical learning and experimental spaces provided by farmers' field schools in Vietnam (Dang 2015); participatory learning through field schools and experimentation (Setiawan and Khumairoh 2014), and action research, participatory monitoring and learning groups for agroforestry in Indonesia (Amaruzaman et al. 2018); formation and strengthening of community management groups and their capacities to advocate for policy change in tandem with promotion of ecological farming and exchange of traditional seed varieties in the Philippines (MRDC and Tebtebba Foundation 2012); and participatory monitoring by community members in Cambodia (Costello and Vorsak 2011). In Southeast Asia, there are more government sectoral ministries engaged in knowledge-based solutions for sustainable use and management. This may help explain why we find a high number of government extension and learning programs for sustainable resource management at local scales.

The preference for livelihood-based solutions that also address food and nutrition security as the largest proportion of economic and incentive-based solution types in South Asia (Figs. 7.1 and 7.2) is illustrated by: investments in new cash crops for income and food sufficiency in Nepal; investments in cooperative farming of fish and single cell algal protein, and proposals for integration of horticulture practices with indigenous fruit species in India; and proposals to diversify livelihood options to reduce poverty in Bhutan (Pandit et al. 2016; ICIMOD 2017; Tekale et al. 2012). The high preference for investments in livelihoods, access to social services, and organizational strengthening may reflect the more basic development needs of the region and the higher incidence of poverty. This focus on items such as access to water and capacity building of local institutions builds the foundation for the sustainable management of SEPLS. There is also a higher abundance of local NGOs and CBOs that may support small development activities to invest in livelihoods and social services as well as civil society institutions that may be able to advocate for citizen needs. Box 7.1 illustrates a profile of multi-stakeholder governance of SEPLS in Nepal, typical of findings in South Asia, and discusses how the composition of societal-based coalitions and solution types interact at local scales. 


\section{Box 7.1 Community Engagement in Navigating Solutions to the Loss of BES in SEPLS in Nepal}

Nepal is a biodiversity-rich country with a multicultural population representing significant ethnic diversity. Nature is considered a complementary part of everyday life, and the majority of people's livelihoods depend on natural resources in a rural economy based on subsistence agriculture. Communities are dependent on the forest for fuelwood, fodder, and timber, and inland freshwater resources for fishing, irrigation, and daily water consumption for drinking, washing, and bathing. SEPLS in Nepal face social and ecological challenges such as low education levels, high use of chemical fertilizer, overharvesting, insufficient infrastructure and social services, and an increasing population density that has led to rising food insecurity challenges.

Nonetheless, local communities are contributing to the effective management of local natural resources through their traditional knowledge and a variety of localized resource-based management systems such as the Federation of Community Forestry User groups, farmer to farmer and community-based cooperatives, community drinking water management groups, and communitybased protected area management (Adhikari 2011; ILEC 2012; UNDP 2014b; Pandit et al. 2016). They often do this through livelihood (economic) and inclusion (institutional) solution sub-types, which are found with the highest frequency in South Asia. Moreover, marginal and indigenous communities undertake entrepreneurial activities through sustainable use of the resources found in the surroundings in which they inhabit. For instance, their beliefs in maintaining an eternal relationship with nature are evident in their development of sustainable solutions for improved local community livelihoods through strategies such as domestication of wild medicinal aromatic plant species (Pandit et al. 2016).

Similar to South Asia as a whole, in Nepal there is an abundance of local NGOs, civil society organizations such as Ward Citizen Forums, and community-based organizations including youth clubs, which are engaged in conservation and restoration activities. These organizations are also actively involved in realizing the significant role of the community in raising awareness to address issues of biodiversity conservation and sustainable use of resources through trainings, workshops, exposure visits, posters and pamphlets, as well as for mobilization and strengthening of community groups (Adhikari 2011; ILEC 2012; UNDP 2014b; Pandit et al. 2016). In Nepal, as in South Asia, there is a strong presence of intergovernmental agencies engaged in project management, and that provide technical support for implementation.

Technical solutions such as ecological conservation and restoration are found most frequently in South Asia. In Nepal, forest area covers $40 \%$ of the total land area, and forest resources make a major contribution to addressing poverty and enhancing the resilience of local communities. Nepal has become 
Box 7.1 (continued)

a successful model of the community forestry management system, which is well known for promoting sustainable management and restoration of the forest. Improving forest-based livelihoods depends on community-based forest management. The system relies on community-based governance through beneficial linkages with concerned stakeholders such as the District Forest Office (DFO), the Federation of Community Forestry User Groups Nepal (FECOFUN), the Department of Forestry (DOF), national and village development committees, and community groups of women, youth and cooperatives. These networks of stakeholders actively work together to provide capacity building to local communities to implement the management schemes (Adhikari 2011). Traditional knowledge is encouraged in meetings, planning, and decision-making processes from the community to the district level forum.

Some specific solutions can be explained by the choices of international research institutions, international NGOs, and private sector actors to invest in programs that aim to meet global conservation and restoration aims and secure international valuechains by increasing benefit streams to local residents of SEPLS. The subsidies, payments, and rewards solutions in Southeast Asia may reflect such international investments in the intensive piloting and promotion of payment for ecosystems services (PES) schemes in countries such as Indonesia, Cambodia, and the Philippines (see for instance Amaruzaman et al. 2018; Costello and Vorsak 2011).

\subsubsection{Meeting the New Challenges for Sustainable Use and Management of SEPLS}

IPSI's experiences in revitalizing sustainable use and management of SEPLS do demonstrate strong efforts across Asia to find solutions through inclusion, which have in some cases strengthened multi-level governance of SEPLS. Place-based solutions emphasize institutional and governance solution types as the most selected solution type, and especially solutions for inclusion, that aim to bring in more collaborative decision-making modes or more equitable benefit sharing of ecosystem services. For instance, inclusion of local people in defining rights to land use can lead to strengthening regulatory systems and institutions governing customary law, connecting local institutions with national forest policy (Shohibuddin and Aoyama 2009).

Moreover, because place-based solutions are already based in collaborative decision-making processes by coalitions of societal actors, these solutions add value to best available knowledge of conservation and restoration solutions and what works across multiple scales. Indeed, existing private sector engagement and 
engagement of international and local research institutions, while present across the region, can be enhanced by stakeholder coalitions that reach out to engage additional actors and continue to encourage inclusive approaches.

Research on governance modes to address the interlinked drivers of a loss of BES increasingly calls for governance by "imagination," or to anticipate what will be needed in an uncertain future shaped by as yet undetermined impacts of climate change and biodiversity loss (Burch et al. 2019). These new states of sustainable use and management need to be resilient states that anticipate and imagine ecosystem service needs in the future as well as the present and that account for potential climate change impacts. In a recent review, Chiu et al. (2018) found that future resilience strategies would get the best return from those solutions that demonstrate co-benefits, or in the case of SEPLS, those that meet the revitalization, adaptation and innovative production and livelihood needs of local residents, while conserving and restoring landscapes for climate mitigation and biodiversity conservation benefits.

Societal actors demonstrate preferences for solution types to reversing the loss of BES in SEPLS while embracing all solution types across ecosystems. In current management practices in mosaic SEPLS, stakeholders rely on different tool-kits for managing BES on a local scale to achieve the same international targets such as the Aichi Biodiversity Targets or Sustainable Development Goals depending on the social-ecological system, stakeholder coalitions, and social-cultural context. This suggests that sustainable use and management to conserve and restore BES on multiple scales can be achieved through varying management strategies.

Experiences in the IPSI network also demonstrate that investments in a spectrum of solution types including cognitive, economic, social and cultural, and technological are needed to meet the challenges of new and effective sustainable use and management approaches. The type of conservation and restoration solutions appropriate in different social-ecological contexts may depend on the composition of stakeholder coalitions, planning systems at social and ecological scales, and the mosaic ecosystem character of SEPLS.

We found overall that institutional and governance solution types are the most frequent at local scales and at all scales combined. This is a good start to developing the coordinated responses at multiple scales that can consider the continuing adaptation and management of ecosystem services in the future (MA 2005), and this can be achieved with the harmonization of solutions in institutions and governance together with solutions in all solution types. Mixes of different solution types with the intention to achieve synergies among biodiversity and production benefits can help address the feedbacks across scales, and among land uses and users, in complex social-ecological systems such as SEPLS.

Further, many of the technological solutions in IPSI member experiences have the potential for multiple benefits, such as renewable energy technologies or ecological farming practices. If these are intentionally combined for better environmental decision-making with knowledge-based solutions, and with institutional and social solutions that can provide supportive policy, management strategies and education and awareness, this will help ensure the realization of these co-benefits in future sustainable use and management of SEPLS. 


\subsubsection{Place-Based Solutions for Sustainable Use and Management of Production Landscapes and Seascapes}

Understanding which place-based solution types are preferred in different socialecological contexts helps improve more purposeful design of SEPLS for multiple benefits, particularly in considering where optimal ecosystem services are not present and where different solution types might increase synergies or reduce trade-offs among land-use choices. Social-cultural approaches are more popular in sustainable use and management of common resources such as forest, while more technical approaches are preferred in management of cultivated lands, which may be more tied to individual farmers' decisions. New sustainable use and management approaches can utilize existing stakeholder preferences exemplified in place-based solutions, but also examine how widening values of multiple stakeholders and coordinated responses might create benefits from inclusion of a different solution type or efforts at a different scale.

For instance, greater engagement of national research institutes and local and national NGOs in South Asia might help incorporate more tailored technical solutions where appropriate. While catchment management and integrated lake basin management approaches have benefited from investments in multi-stakeholder governance, knowledge or cognitive solutions that are currently less utilized in the East and South Asia sub-regions could lift inadequate use of knowledge. Linking integrated management (an institutional solution) with monitoring and evaluation systems (knowledge solution) could help bring about more robust SEPLS management that integrates multiple knowledge forms from indigenous and practical sources, and creates local information systems such as participatory monitoring that can monitor feedbacks across scales.

Some limitations of sustainable use and management approaches in SEPLS can be improved. While integrated landscape and transboundary approaches are gaining popularity, we found that place-based solutions are targeted mainly in cultivated and forest ecosystems. Further, there hasn't yet been a shift to planning the majority of agricultural and forest ecosystem transformations at landscape or ecological scales because the institutional architecture is embodied in village and district or municipality governance systems, while ecosystem services may not have any bearing on these scales. This may be true particularly in Southeast Asia where the most common composition of stakeholder coalitions in SEPLS is the interaction of sectoral ministries with communities through planning at social and administrative scales. Further, mountain ecosystems, drylands, and urban areas do not receive any of the benefits of planning at an eco-regional scale that might consider the flows of ecosystem services. In some cases, dryland, urban, and island ecosystems may benefit from more integrated landscape approaches at administrative scales as they are typically tackled at higher scales from district to national levels. Island ecosystems may correspond to a district or municipality and benefit from synching of ecological and social scales. This would entail more deliberate spatial planning that bridges social 
and ecological knowledge, and that gives consideration to the interactions of drivers and solution types at different scales and in different ecosystems from among the full suite of technical, social, institutional, economic, and knowledge-based solutions.

Deliberate place-based planning for sustainable use and management that will enable future resilient SEPLS should take advantage of community-led innovations, multi-level governance approaches, and solution mixes that include social, cultural, and knowledge-based approaches along with context-dependent technical and economic solutions (Bohnet and Beilin 2015). As urban areas expand, planning for these areas that incorporates multiple solution types can enhance their resilience, especially when solution mixes are selected for multiple goals, and for future resilience across urban-rural landscapes (Wendling et al. 2018; Eggermont et al. 2015). This kind of design fits with broader approaches to planning solutions in SEPLS in ways that support policy design for the Anthropocene, where synergies among solutions are key to balancing trade-offs and staying within planetary boundaries through connected places (Sterner et al. 2019).

\subsection{Conclusions}

The drivers of overconsumption, urbanization, modernization of agriculture, underutilization and industrialization, among others, and their interactions and cumulative effects are accelerating the loss of BES in SEPLS in Asia, and causing imbalances in formerly harmonious approaches to sustainable use and management. Externally influenced drivers and societal actors from all scales are part of the challenges but are also part of the solutions. IPSI members demonstrate that communities in SEPLS across Asia are working with multiple partners at different scales to revitalize social-ecological production landscapes and seascapes in ways that will address the drivers of BES loss. In many cases, they are also helping to revitalize a state of sustainable use and management that delivers ecosystem service benefits in the form of production income, dietary diversity, and increased health and wellbeing, while providing conservation and restoration benefits that benefit ecosystems and environmental health at multiple scales.

Through working with multiple stakeholders to devise institutional, cognitive, economic, social and cultural, and technological responses across ecosystems and scales, communities in SEPLS in Asia are responding to the need to devise solutions across ecosystems and scales and to consider feedbacks among social-ecological systems to revitalize a balance among the multiple ecosystems services for food, forests, biodiversity, and livelihoods. As demonstrated by the wide breadth of societal actors working jointly on solutions in SEPLS, the representation across stakeholder groups, and varying composition of coalitions, the IPSI network is contributing to the best available knowledge that reflects the pluralistic values of multiple stakeholders in identifying which solutions are preferable in different social-ecological systems. 
Understanding which solution types societal actors have chosen to implement or have proposed in SEPLS in different sub-regions and social-ecological contexts in Asia gives us an understanding as to what might be the criteria for effectiveness applied by societal actors. Sharing the knowledge of which solution types are preferred in different social-ecological contexts may help societal actors make better informed decisions in weighing the appropriateness of different solutions in SEPLS. The framework proposed here for analyzing solutions by type, scale, and ecosystem can be done in a local context through a transdisciplinary approach to help coalitions of actors take note of gaps and devise place-based sustainable use and management approaches for conservation and restoration of BES in SEPLS.

Our results and findings are limited by the small number of cases available from certain ecosystems such as drylands and the relative lack of cases in Satoumi (coastal ecosystems). We were also limited by a lack of spatial data that could inform the placement of solutions in mosaic ecosystems of SEPLS. Future studies may seek to measure the performance and impact of different solutions and their combinations, and to disaggregate the solutions by existing and proposed in further analysis.

Acknowledgements We would like to thank Geetha Mohan at UNU-IAS and two anonymous reviewers for their comments on an earlier version of the manuscript. We thank the International Satoyama Initiative and the Ministry of Environment Japan for their support of this work.

\section{References}

Aadrean UN (2017) Small-clawed otters (Aonyx cinereus) in Indonesian rice fields: latrine site characteristics and visitation frequency. Ecol Res 32(6):899-908

Adhikari S (2011) Community forestry in Nepal. Case studies, International Partnership for the Satoyama Initiative. https://satoyama-initiative.org/casestudies

Akça E, Takashi K, Sato T (2015) Development and success, for whom and where: the Central Anatolian case. Land restoration: reclaiming landscapes for a sustainable future. Academic Press, Oxford, pp 533-541

Amaruzaman S, Lusiana B, Leimona B, Tanika L, Hendrawan DC (2018) Strengthening smallholder resilience and improving ecosystem services provision in Indonesia: experience from Buol District, Central Sulawesi. Case studies, International Partnership for the Satoyama Initiative. https://satoyama-initiative.org/casestudies

Bélair C, Ichikawa K, Wong BYL, Mulongoy KJ (2010) Sustainable use of biological diversity in socio-ecological production landscapes. Background to the Satoyama Initiative for the benefit of biodiversity and human well-being. Secretariat of the Convention on Biological Diversity, Montreal. Technical Series no. 52, 184 pages

Berglund BE, Kitagawa J, Lageras P, Nakamura K, Sasaki N, Yasuda Y (2014) Traditional farming landscapes for sustainable living in Scandinavia and Japan: global revival through the Satoyama Initiative. AMBIO 43:559-578

Bohnet IC, Beilin R (2015) Editorial: pathways towards sustainable landscapes. Sustain Sci 10:187-194

Burch S, Gupta A, Inoue CYA, Kalfagianni A, Persson A, Gerlak AK, Ishii A, Patterson J, Pickering J, Scobie M, Van der Heijden J, Vervoort J, Adler C, Bloomfield M, Djalante R, Dryzek J, Galaz V, Gordon C, Harmon R, Jinnah S, Kim RE, Olsson L, Van Leeuwen J, Ramasar V, Wapner 
P, Zondervan R (2019) New directions in earth system governance research. Earth Syst Gov $1: 100006$

Chao JT (2018) Converting pests into allies in tea farming — a SEPL case in Hualien. Case studies, International Partnership for the Satoyama Initiative. https://satoyama-initiative.org/casestudies

Chiu B, Zusman E, Lee S, Jian H (2018) The co-benefits of integrated solutions in Asia: an analysis of governance challenges and enablers. In: Zusman E, Amanuma N (eds) Governance for integrated solutions to sustainable development and climate change: from linking issues to aligning interests. Institute for Global Environmental Strategies (IGES), Tokyo, pp 21-37

Cockburn J, Cundill G, Shackleton S, Rouget M (2018) Towards place-based research to support social-ecological stewardship. Sustainability 10:1434

Costello L, Vorsak B (2011) Natural resource management in the critical habitat of Western Siem Pang. Case studies, International Partnership for the Satoyama Initiative. https://satoyamainitiative.org/casestudies

Dang KT (2015) The importance of the Farmers Field School approach: a case study-Farmers Field School practical training programs, Vietnam. Case studies, International Partnership for the Satoyama Initiative. https://satoyama-initiative.org/casestudies

Dicks LV, Wright HL, Ashpole JE, Hutchison J, McCormack CG, Livoreil B, Zulka KP, Sutherland WJ (2016) What works in conservation? using expert assessment of summarised evidence to identify practices that enhance natural pest control in agriculture. Biodivers Conserv 25:1383-1399

Duraiappah AK, Tanyi AST, Brondizio ES, Kosoy N, O'Farrell PJ, Prieur-Richard AH, Subramanian SM, Takeuchi KC (2014) Managing the mismatches to provide ecosystem services human well-being: a conceptual framework for understanding the new commons. Curr Opin Environ Sustain 7:94-100

Eggermont H, Balian E, Azevedo JMN, Beumer V, Brodin T, Claudet J, Fady B, Grube M, Keune H, Lamarque P, Reuter K, Smith M, van Ham C, Weisser WW, Le Roux X (2015) Naturebased solutions: new influence for environmental management and research in Europe. GAIA 24(4):243-248

Fan ML, Yu CY, Lin L (2016) Indicator species for agrobiodiversity in rice paddy fields: research and its application to a new eco labelling scheme in eastern rural Taiwan. Case studies, International Partnership for the Satoyama Initiative. https://satoyama-initiative.org/casestudies

Freeman OE, Duguma LA, Minang PA (2015) Operationalizing the integrated landscape approach in practice. Ecol Soc 20(1):24

Gu H, Subramanian SM (2014) Drivers of change in socio-ecological production landscapes: implications for better management. Ecol Soc 19(1):41

Hashimoto S, Nakamura S, Saito O, Kohsaka R, Kamiyama C, Tomiyoshi M, Kishioka T (2015) Mapping and characterizing ecosystem services of social-ecological production landscapes: case study of Noto, Japan. Sustain Sci 10(2):257-273

Havas J, Saito O, Hanaki K, Tanaka T (2016) Perceived landscape values in the Ogasawara Islands. Ecosyst Serv 18:130-140

Hernández-Morcillo M, Burgess P, Mirck J, Pantera A, Plieninger T (2018) Scanning agroforestrybased solutions for climate change mitigation and adaptation in Europe. Environ Sci Policy $80: 44-52$

Ichikawa K (2012) China: rural communities in cohabitation with the Crested Ibis in Yang County, Shaanxi Province. Case studies, International Partnership for the Satoyama Initiative. https:// satoyama-initiative.org/casestudies

ICIMOD (International Centre for Integrated Mountain Development), Nepal, Royal Society for Protection of Nature (2017) A multi-dimensional assessment of ecosystems and ecosystem services in Barshong, Bhutan. Case studies, International Partnership for the Satoyama Initiative. https://satoyama-initiative.org/casestudies

ILEC (International Lake Environment Committee Foundation) (2012) Governance at community level for conserving Himalayan Lake Rupa in Kaski District of Nepal. Case studies, International Partnership for the Satoyama Initiative. https://satoyama-initiative.org/casestudies 
IPBES (Intergovernmental Science-Policy Platform on Biodiversity and Ecosystem Services) (2015) Preliminary guide regarding diverse conceptualization of multiple values of nature and its benefits, including biodiversity and ecosystem functions and services (deliverable 3(d)). IPBES/4/INF/13

IPBES (Intergovernmental Science-Policy Platform on Biodiversity and Ecosystem Services) (2018) Summary for policymakers of the regional assessment report on biodiversity and ecosystem services for Asia and the Pacific of the Intergovernmental Science-Policy Platform on Biodiversity and Ecosystem Services. IPBES Secretariat, Bonn. (41 pages)

Jacobs S, Dendoncker N, Martín-López B, Barton DN, Gomez-Baggethun E, Boeraeve F, McGrath FL, Vierikko K, Geneletti D, Sevecke KJ, Pipart N, Primmer E, Mederly P, Schmidt S, Aragão A, Baral H, Bark RH, Briceno T, Brogna D, Cabral P, De Vreese R, Liquete C, Mueller H, Peh KSH, Phelan A, Rincón Ruiz A, Rogers SH, Turkelboom F, Van Reeth W, van Zanten BT, Wam HK, Washbourne CL (2016) A new valuation school: integrating diverse values of nature in resource and land use decisions. Ecosyst Serv 22(b):213-220

Katayama N, Baba YG, Kusumoto Y, Tanaka K (2015) A review of postwar changes in rice farming and biodiversity in Japan. Agric Syst 132:73-84

Khan K, Ikram, M, Takahi, S, Iqbal R (2017) Socio-ecological landscape change as a preamble to mountainous urban watershed rejuvenation, Kanshi of the Jhelum River Basin, Potohar Plateau, Pakistan. Case studies, International Partnership for the Satoyama Initiative. https:// satoyama-initiative.org/casestudies

Kieninger PR, Yamaji E, Penker M (2011) Urban people as paddy farmers: the Japanese Tanada Ownership System discussed from a European perspective. Renew Agric Food Syst 26(4):328-341

Knight C (2010) The discourse of "encultured nature" in Japan: the concept of Satoyama and its role in 21st century nature conservation. Asian Stud Rev 34(4):421-441

Kohsaka R, Shih W, Saito O, Sadohara S (2013) Local assessment of Tokyo: Satoyama and satoumi-traditional landscapes and management practices in a contemporary urban environment. In: Elmqvist T, Fragkias M, Goodness J, Güneralp B, Marcotullio PJ, McDonald RI, Parnell S, Schewenius M, Sendstad M, Seto KC, Wilkinson C (eds) Urbanization, biodiversity and ecosystem services: challenges and opportunities: a global assessment. Springer, Dordrecht, pp 93-105

Kozar R, Galang E, Alip A, Sedhain J, Subramanian SM, Saito O (2019) Multi-level networks for sustainability solutions: the case of the International Partnership for the Satoyama Initiative. Curr Opin Environ Sustain 39:123-134

Kumar BM, Takeuchi K (2009) Agroforestry in the Western Ghats of peninsular India and the satoyama landscapes of Japan: a comparison of two sustainable land use systems. Sustain Sci 4(2):215-232

Li S, Li X (2016) Progress and prospect on farmland abandonment. Dili Xuebao/Acta Geogr Sin 71(3):370-389

MA (Millennium Ecosystem Assessment) (2005) Millennium Ecosystem Assessment. Ecosystems and human well-being: synthesis. Island Press, Washington, DC. (155 pages)

Marady I, Sokla H, Mary S (2011) Role and involvement of the commune council in community forestry activities in Domnak Neak Tathmor Puan. Case studies, International Partnership for the Satoyama Initiative. https://satoyama-initiative.org/casestudies

Matsui T, Kawashima T, Kasahara T (2010) Town revitalization making the most of natural landscape and traditions of Kanakura Wajima City, Ishikawa Prefecture, Japan. Case studies, International Partnership for the Satoyama Initiative. https://satoyama-initiative.org/casestudies

Morimoto Y (2011) What is Satoyama? Points for discussion on its future direction. Landsc Ecol Eng 7(2):163-171

MRDC (Montañosa Research and Development Center), Tebtebba Foundation (2012) Role of traditional knowledge in strengthening socio-ecological production landscapes. Case studies, International Partnership for the Satoyama Initiative. https://satoyama-initiative.org/casestudies 
Ohsako Y (2011) Reintroduction project of the Oriental White Stork for coexistence with humans in satoyama areas, Hyogo, Japan. Case studies, International Partnership for the Satoyama Initiative. https://satoyama-initiative.org/casestudies

Okayasu S, Matsumoto I (2013) Contributions of the Satoyama initiative to mainstreaming sustainable use of biodiversity in production landscapes and seascapes. Institute for Global Environmental Strategies (IGES), Tokyo. (44 pages)

Oliver TH, Heard MS, Isaac NJB, Roy DB, Procter D, Eigenbrod F, Freckleton R, Hector A, Orme CDL, Petchey OL, Proença V, Raffaelli D, Suttle KB, Mace GM, Martín-López B, Woodcock BA, Bullock JM (2015) Biodiversity and resilience of ecosystem functions. Trends Ecol Evol 30(11):673-684

Osawa T, Kohyama K, Mitsuhashi H (2016) Multiple factors drive regional agricultural abandonment. Sci Total Environ 542:478-483

Pandit BH, Lopez-Casero MF, Pandit NR, Aryal NK (2016). Strengthening local capacity for conserving medicinal plants and improving livelihoods through domestication and integration of LBSAP in planning process. In: UNU-IAS and IGES (ed) Mainstreaming concepts and approaches of socio-ecological production landscapes and seascapes into policy and decisionmaking (Satoyama initiative thematic review, vol 2). United Nations University Institute for the Advanced Study of Sustainability, Tokyo, pp 85-95

Pascual U, Balvanera P, Díaz S, Pataki G, Roth E, Stenseke M, Watson RT, Başak Dessane E, Islar M, Kelemen E, Maris V, Quaas M, Subramanian SM, Wittmer H, Adlan A, Ahn S, Al-Hafedh YS, Amankwah E, Asah ST, Berry P, Bilgin A, Breslow SJ, Bullock C, Cáceres D, Daly-Hassen H, Figueroa E, Golden CD, Gómez-Baggethun E, González-Jiménez D, Houdet J, Keune H, Kumar R, Ma K, May PH, Mead A, O'Farrell P, Pandit R, Pengue W, Pichis-Madruga R, Popa F, Preston S, Pacheco-Balanza D, Saarikoski H, Strassburg BB, van den Belt M, Verma M, Wickson F, Yagi N (2017) Valuing nature's contributions to people: the IPBES approach. Curr Opin Environ Sustain 26-27:7-16

Plieninger T, van der Horst D, Schleyer C, Bieling C (2014) Sustaining ecosystem services in cultural landscapes. Ecol Soc 19(2):59

Plieninger T, Kohsaka R, Bieling C, Hashimoto S, Kamiyama C, Kizos T, Penker M, Kieninger P, Shaw BJ, Sioen GB, Yoshida Y, Saito O (2018) Fostering biocultural diversity in landscapes through place-based food networks: a "solution scan" of European and Japanese models. Sustain Sci 13:219-233

Putra RE, Nakamura K (2009) Foraging ecology of a local wild bee community in an abandoned Satoyama system in Kanazawa, Central Japan. Entomol Res 39(2):99-106

Queiroz C, Beilin R, Folke C, Lindborg R (2014) Farmland abandonment: threat or opportunity for biodiversity conservation? A global review. Front Ecol Environ 12(5):288-296

Sakurai R, Ota T, Uehara T, Nakagami K (2016) Factors affecting residents' behavioral intentions for coastal conservation: case study at Shizugawa Bay, Miyagi, Japan. Mar Policy 67:1-9

Setiawan A, Khumairoh U (2014) Diversifying forage composition to improve milk production and quality through participatory learning. Case studies, International Partnership for the Satoyama Initiative. https://satoyama-initiative.org/casestudies

Shimada D (2015) Multilevel natural resources governance based on local community: a case study of seminatural grassland in Tarōji, Nara, Japan. Int J Commons 9(2):486-509

Shohibuddin M, Aoyama G (2009) Creation and management of diverse secondary forest in Central Sulawesi, Indonesia. Case studies, International Partnership for the Satoyama Initiative. https:// satoyama-initiative.org/casestudies

Springmann M, Mason-D'croz D, Robinson S, Garnett T, Charles H, Godfray J, Scarborough P (2016) Global and regional health effects of future food production under climate change: a modelling study. Lancet 387(10031):1937-1946

Sterner T, Barbier EB, Bateman I, van den Bijgaart I, Crépin AS, Edenhofer O, Fischer C, Habla W, Hassler J, Johansson-Stenman O, Lange A, Polasky S, Rockström J, Smith HG, Steffen W, Wagner G, Wilen JE, Alpízar F, Azar C, Carless D, Chávez C, Coria J, Engström G, Jagers SC, Köhlin G, Löfgren A, Pleijel H, Robinson A (2019) Policy design for the Anthropocene. Nat Sust 2:14-21 
Subramanian SM, Kaoru I, Ayako K (2015) Enhancing knowledge for better management of socio-ecological production landscapes and seascapes: appropriate tools and approaches for effective action. In: UNU-IAS and IGES (ed) Enhancing knowledge for better management of socio-ecological production landscapes and seascapes (SEPLS) (Satoyama initiative thematic review, vol 1). United Nations University Institute for the Advanced Study of Sustainability, Tokyo, pp 1-7

Subramanian SM., Chakraborty S, Ichikawa K (2016) Toward mainstreaming concepts and approaches of socio-ecological production landscapes and seascapes (SEPLS): lessons from the field. In: UNU-IAS and IGES (ed) Mainstreaming concepts and approaches of socio-ecological production landscapes and seascapes into policy and decision-making (Satoyama initiative thematic review, vol 2). United Nations University Institute for the Advanced Study of Sustainability, Tokyo. pp 1-12

Subramanian SM, Chakraborty S, Leimona B (2017) Sustainable livelihood options in SEPLS for human well-being. In: UNU-IAS and IGES (ed) Sustainable livelihoods in socio-ecological production landscapes and seascapes (Satoyama initiative thematic review, vol 3). United Nations University Institute for the Advanced Study of Sustainability, Tokyo, pp 1-11

Subramanian SM, Yiu E, Leimona B (2018) Enhancing effective area-based conservation through the sustainable use of biodiversity in socio-ecological production landscapes and seascapes (SEPLS). In: UNU-IAS and IGES (ed) Sustainable use of biodiversity in socio-ecological production landscapes and seascapes and its contribution to effective area-based conservation (Satoyama initiative thematic review, vol 4). United Nations University Institute for the Advanced Study of Sustainability, Tokyo, pp 1-13

Sutherland WJ, Gardner T, Bogich TL, Bradbury RB, Clothier B, Jonsson M, Kapos V, Lane SN, Möller I, Schroeder M, Spalding M, Spencer T, White PCL, Dicks LV (2014) Solution scanning as a key policy tool: identifying management interventions to help maintain and enhance regulating ecosystem services. Ecol Soc 19(2):3

Sutherland WJ, Dicks LV, Ockendon N, Smith RK (2017) What works in conservation 2017. Open Book Publishers, Cambridge. (445 pages)

Takeuchi K, Ichikawa K, Elmqvist T (2016) Satoyama landscape as social-ecological system: historical changes and future perspective. Curr Opin Environ Sustain 19:303

Tekale NS, Kodarkar MS, Karnik P, Singh R (2012) Integrated lake basin management (ILBM), impacts on biodiversity and child malnutrition: a case study of tribal belt in western part of India. Case studies, International Partnership for the Satoyama Initiative. https://satoyamainitiative.org/casestudies

Tomita A, Nakura Y, Ishikawa T (2015) Review of coastal management policy in Japan. J Coast Conserv 19(4):393-404

Toyooka City (2012) Community development to live in harmony with the Oriental White Stork in Toyooka City, Hyogo, Japan. Case studies, International Partnership for the Satoyama Initiative. https://satoyama-initiative.org/casestudies

Tsuchiya K, Okuro T, Takeuchi K (2013) The combined effects of conservation policy and comanagement alter the understory vegetation of urban woodlands: a case study in the Tama Hills area, Japan. Landscape Urban Plan 110(1):87-98

UNDP (United Nations Development Programme) (2014a) Communities in action for landscape resilience and sustainability - the COMDEKS Programme. United Nations Development Programme, New York

UNDP (United Nations Development Programme) (2014b) COMDEKS project: Makawanpur District. Communities in action for landscape resilience and sustainability-the COMDEKS Programme. United Nations Development Programme, New York, pp 110-121

UNDP (United Nations Development Programme) (2016) A community-based approach to resilient and sustainable landscapes: lessons from phase II of the COMDEKS Programme. UNDP, New York

UNU-IAS (United Nations University Institute for the Advanced Study of Sustainability) (2012a) South Korea: traditional rural landscape "Maeul". In: Ichikawa K (ed) Socio-ecological pro- 
duction landscapes in Asia. United Nations University Institute for the Advanced Study of Sustainability, Tokyo, pp 29-33

UNU-IAS (United Nations University Institute for the Advanced Study of Sustainability) (2012b) Socio-ecological production landscapes in Asia. In: Ichikawa K (ed). United Nations University Institute for the Advanced Study of Sustainability, Tokyo

UNU-IAS (United Nations University Institute for the Advanced Study of Sustainability) (2012c) Philippines: a combination of rice terraces, Swidden and Muyong (Privately Owned Forests) in the Province of Ifugao UNU-IAS. 2012. In: Ichikawa K (ed) Socio-ecological production landscapes in Asia. United Nations University Institute for the Advanced Study of Sustainability, Tokyo, pp 75-78

UNU-IAS (United Nations University Institute for the Advanced Study of Sustainability) (2018) Case study database

van Oudenhoven FJW, Mijatović D, Eyzaguirre PB (2010) Bridging managed and natural landscapes: the role of traditional (agri)culture in maintaining the diversity and resilience of socialecological systems. In: Bélair C, Ichikawa K, Wong BYL, Mulongoy KJ (Eds) Sustainable use of biological diversity in socio-ecological production landscapes: background to the 'Satoyama Initiative for the benefit of biodiversity and human well-being.' Secretariat of the Convention on Biological Diversity. Montreal. Technical Series no. 52, pp 8-21

Wendling LA, Aapo H, zu Castell-Rüdenhausen M, Hukkalainen M, Airaksinen M (2018) Benchmarking nature-based solution and smart city assessment schemes against the sustainable development goal indicator framework. Front Environ Sci 6:69

Yiping L (2011) Productive bamboo landscapes of Western Zhejiang. Case studies, International Partnership for the Satoyama Initiative. https://satoyama-initiative.org/casestudies.

Yu H, Verburg PH, Liu L, Eitelberg DA (2016) Spatial analysis of cultural heritage landscapes in Rural China: land use change and its risks for conservation. Environ Manag 57(6):1304-1318

Yun-Ju F, Bo-Wen S, Chuan-Kai H, Wen-Tsui L (2015). Facilitating biological and freshwater resource conservation by agricultural activities at Gongliao-Hoho-Terraced-Paddy-Fields, Taiwan. Case studies, International Partnership for the Satoyama Initiative. https://satoyamainitiative.org/casestudies

Open Access This chapter is licensed under the terms of the Creative Commons Attribution 4.0 International License (http://creativecommons.org/licenses/by/4.0/), which permits use, sharing, adaptation, distribution and reproduction in any medium or format, as long as you give appropriate credit to the original author(s) and the source, provide a link to the Creative Commons licence and indicate if changes were made.

The images or other third party material in this chapter are included in the chapter's Creative Commons licence, unless indicated otherwise in a credit line to the material. If material is not included in the chapter's Creative Commons licence and your intended use is not permitted by statutory regulation or exceeds the permitted use, you will need to obtain permission directly from the copyright holder.

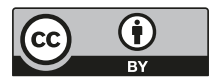

